Nordic Journal of Religion and Society (2009), 22 (2): 103-121

\title{
Linda Woodhead
}

\section{Old, New, And EMERging Paradigms In The SOCIOLOGICAL STUdy OF RELIGION}

\section{Abstract}

\begin{abstract}
This article argues that a significant shift is taking place in the sociological study of religion, and seeks to outline its main features. In order to do so it returns to Stephen Warner's classic article of 1993 which drew a contrast between 'old' and 'new' paradigms in the sociology of religion. It develops Warner's analysis by setting these paradigms in their European and American contexts respectively, and argues that there are signs of a third, 'emerging' paradigm which moves beyond these dichotomous alternatives. Not by coincidence, the emerging paradigm also moves beyond methodological nationalism, taking a more global view of religion. In addition, it breaks free from captivity to a single theoretical perspective (whether 'secularisation'/religious decline or 'rational choice'/religious vitality), and embraces broader theoretical, conceptual, and methodological possibilities.
\end{abstract}

Key words: sociology of religion, method, theory, material culture, globalization, power

What is happening to the sociology of religion? Is it 'business as usual', or are there signs of upheaval and change? My sense is that a significant shift is underway, and in this article - based on a plenary paper delivered at the Nordic Conference for the Sociology of Religion in 2008 - I try to discern some of the contours of change. ${ }^{1}$

A key inspiration in this task is Stephen Warner's much-cited article: 'Work in Progress Towards a New Paradigm in the Sociology of Religion', which appeared in the American Journal of Sociology in 1993. Warner's article was one of the first to try to make sense of changes in the sub-discipline, which he articulated in terms of a shift from an 'old' theoretical paradigm stemming from Europe towards a 'new' paradigm stemming from the USA - a shift which he both documented and advocated.

In this article I revisit Warner's contrast between the old and new paradigms and take it further. I develop it in two main ways: first, by drawing out aspects of Warner's scheme which he did not cover, particularly its methodological implications; second, by suggesting that further change has taken place since the time he article was published: to such an extent that we can now discern an 'emerging' paradigm which differs in important ways from both the old and the new paradigms on which he focused attention. 


\section{The old paradigm}

Since the publication of his article, Warner has made it clear that what he loosely called a 'paradigm' is a gestalt, a way of seeing or a guiding framework. 'A paradigm', he says, is 'a way of seeing the world, a representation, picture or narrative of the fundamental properties of reality' (Warner 2005:64). As I read Warner - against critics like Frank Lechner (1997) - he wasn't really talking about all hitherto existing sociology of religion, from Weber to Durkheim, but about an influential generation of scholars which, in Europe, included Peter Berger, Bryan Wilson, and David Martin. In connection with the old paradigm, Warner himself mentioned by name Peter Berger (above all), Talcott Parsons, Frank Lechner, James Davison Hunter, and Olivier Tschannen.

Warner characterises the old paradigm in terms of its main theoretical and conceptual assumptions. One of his key moves is to make a connection between the concrete historical and empirical kinds of religion which sociologists privilege, and the ways in which they approach the concept of religion more generally. He suggests that the 'old paradigm' is invisibly shaped by a preoccupation with the historic European mode of religion whereby established churches maintained a cultural monopoly in their own territories, whilst throwing what Berger (1967) called a 'sacred canopy' over the whole of society.

Warner has an enormously important point here, and one which bears repeating. It cannot be emphasised enough within the sociology of religion that what sociologists label as 'religion' carries their own assumptions about what counts as 'real religion', assumptions shaped by their own social contexts and cultural experiences. What Warner reminds us is how 'exceptional' the historic European mode of religion is. To put it starkly, churches are unique to Europe (at least Europe in the broadest sense, including Orthodox lands). Religious institutions of this kind, with their peculiar ties to cultural and political power, do not exist elsewhere in the world. In America, as Richard Niebuhr (1987/1929) pointed out, there are denominations rather than churches - and these days, even denominations take second place to congregations and autonomous religious gatherings. Of course European-style churches can be exported, as in the case of the Catholic and Anglican churches, but their non-European manifestations cannot retain the same relations with social power as in their original locations, especially in post-colonial contexts.

Warner's point can be elaborated. As I argue in my Introduction to Christianity (Woodhead 2004), historic European churches can never wholly dissociate themselves from their ties to the 'Christendom' project. I define the latter as the project whereby European churches sought for more than a thousand years - with a good deal of success - to achieve a cultural monopoly, such that every 'soul' would be born and raised, think and feel, live and die, within the framework which his or her church approved (a project which sought and involved the co-operation of political power). One corollary of this legacy is that European church leaders considered themselves part of the power elite of their countries. Another is that the national churches had a key role in defining national identity; although that role has been reduced, many still do. It is useful to remind ourselves how recently and reluctantly the Christendom project was surrende- 
red in Europe, and how strong its traces remain. As McLeod (2007) argues so cogently in The Religious Crisis of the 1960s, it was only after the 1950s that the project really lost its force and conviction. In religious terms, Europe is therefore better described as 'post-Christendom' than as 'post-Christian'.

Warner reminds us of all this, not by looking at the European case in any detail, but simply by showing that there is another way to think about religion, even within a predominantly Christian society: the 'new paradigm', American way. The reason he thinks the old paradigm is now outdated is that it is bound up with the equally anachronistic Christendom mode of European religion. In his view, this explains why the old paradigm is also so monomaniacally focused upon secularisation, and why it views the latter as the inevitable outcome of general processes of modernisation. If religion is conceived as a major institutional domain in society with close links to the political domain, and with an overarching function of cultural legitimation, then processes of modernisation like social differentiation and pluralisation inevitably undermine it. In other words, if Christendom (illicitly) furnishes the model for all religion, then the decline of the unifying and extensive influence of monopolistic churches in their territories is interpreted not simply as the decline of a particular mode of European religiosity but as the decline of religion per se under the conditions of modernity.

In effect, Warner is suggesting that where old-paradigm sociology of religion has gone wrong is in elevating historical contingency to the level of general theory. The consequence, he argues, has been the concentration of research interest on an unduly narrow range of themes: religious decline, the erection and maintenance of plausibility structures (as if religious survival needs special explanation); religious professionals and bureaucracies; ascriptive rather than 'achieved' religious identities; religion as a force of social cohesion and legitimation, rather than change (Warner 1993: 1081).

\section{The new paradigm}

Turning then to Warner's 'new paradigm', we can see that this also revolves around a postulated dialectic between a characteristic mode of religion and a particular approach to such religion. Here we cross the Atlantic from east to west, and place our feet firmly on American - specifically United States of American - soil. Although it is true that the Christendom project was exported here - not only in the shape of Anglicanism and Catholicism, but also Congregationalism - the pluralistic socio-religious make up of the United States, and the outworking of the First Amendment to the Constitution, fairly quickly led to the dominance of denominational and congregational models. The denomination and the associated or independent congregation became the basic units of religious life. They differ enormously from European churches by virtue of being (a) voluntary bodies with (b) constitutional separation from the state which (c) do not strive for a cultural monopoly, but chiefly for the souls of their own members, for which they (d) proselytise energetically, in a competitive religious 'market' (Woodhead 2004). 
Warner argues that the American approach to this very different religious landscape is appropriately different from the European one. It is this approach which he identifies as the new paradigm. Rather than focusing on religious decline under the pressures of structural change, it focuses on religious vitality. Hence it has more interest in the lives than the deaths (or anomalous survivals) of denominations and congregations. Unlike the old paradigm, the new one considers not only what religious organisations have to offer (supply side) but also what religious consumers want (demand side). It views religion not as a public service which is involuntarily imposed on a relatively passive population, but as a competitive marketplace in which a plurality of different suppliers vie for market share and seek to provide the products which consumers desire.

For the new paradigm then, American religion succeeds by virtue of offering a plurality of religious 'goods' for an equally plural and demanding market - though even to put it that way is to underplay the active role of individuals. For Warner and those whose empirical work he cites, entrepreneurial groups and individuals in the USA are responsible for founding and developing the vast range of American congregations. Far from having their initiative crushed by existing religious monopolies, as in Europe, they have in America an unrivalled opportunity to establish new forms of religious offering, and to gain significantly from doing so. The gains include not only personal material success, but political leverage, ethnic solidarity, and maintenance of identity. Individual consumers are also more important in an American context. They do not just take what they can get from a monopoly supplier, but play an active role in demanding what they need, and switching loyalties if they don't get it. Because barriers to entry are lower than in Europe, any individual or group in the USA has the opportunity to establish a new congregation, if they cannot find what they want in the existing religious marketplace.

The importance of different ethnic and interest groups establishing their own religious supply is important for Warner, and for the new paradigm as he characterises it. Citing Will Herberg's (1960) reflections, plus a wide range of empirical case studies, Warner argues that the fact that American citizenship requires a loss of linguistic and cultural distinctiveness intensifies the role of religion as the place where distinctive identities can be retained and celebrated - whether of Norwegian Lutherans, Hispanic Catholics, black activists, orthodox Jews, or gay and lesbian Christians. Such groups, according to Warner and the new paradigm, succeed not by aligning with the state and political power, but by empowering their members and supplying their needs. By providing social space for a wide range of cultural and ethnic commitments - resulting in not so much a melting pot as a colourful patchwork of diverse voluntaristic associations in which everyone can find a home - diversity can be contained, sacralised and, on occasion, mobilised politically.

One example which Warner offers is that of the Civil Rights movement in the USA, a movement which led to very significant political change and gains for the black minority, and whose impetus, leadership and support was drawn mainly from black congregations. Another example concerns the way in which women use religion to improve their status and opportunities, whether by finding security and support for their domestic vocation in conservative forms of religion (e.g. Ammerman 1987; 
Davidman 1991), or, in the nineteenth century, by uniting them in a moral crusade for the rights of women which is the forerunner of the feminist movement (e.g. Cott 1977; Smith-Rosenberg 1985). In other words, for the new paradigm, religion in the USA is viewed not so much as an instrument of political power exercised from on high - as in Europe and the old paradigm - but as a resource for empowerment from below. The old paradigm is wrong to focus solely on religion's role in social legitimation, when its role in social change is equally worthy of attention.

All of this means that the new paradigm is able to explain religious vitality in a way that the old is not. For the latter the persistence of religion remains an anomaly to be explained by means of special pleading (regarding 'plausibility structures', 'cultural defence' and so on). For the former, it is explicable in terms of religion's ability to supply goods which people desire more effectively than its competitors. Moreover, the new paradigm is able to explain stasis or decline not in terms of inexorable processes of modernity, but in terms of some blockage in the relation between supply and demand. Thus in relation to Europe, 'rational choice theory' explains religious decline in terms of the lack of competition which occurs when a monopoly supplier (the historic churches) dominate the marketplace, make other 'start-ups' difficult or impossible, and themselves fail to offer the religious goods which consumers demand.

Rational Choice Theory or 'RCT' has become a 'school' since Warner wrote his article, and its particular rendering of the new paradigm has achieved increasing visibility and influence in American sociology of religion. Although Warner notices the early work of writers like Laurence Iannaccone and Finke and Rodney Stark in his article, and identifies them as contributors to the new paradigm, for him the latter is broader than what RCT has become. RCT is a theory narrowly conceived, not a paradigm in Warner's sense, which seeks, in a positivist fashion, to explain and predict religious growth. It focuses on the free, rational (and easily measurable) choices of individuals to the neglect of social forces, and it elevates the market metaphor - and very a particular interpretation of the market - to the status of description. None of this is straightforwardly endorsed by Warner's broader vision of what constitutes the new paradigm, which is open to a much wider range of readings of the market model, and a much more encompassing intellectual project. Warner can easily claim that RCT was not what he had in mind when he first wrote about new paradigm. Yet even as he described it then, the new paradigm contained biases and limitations which, whilst they did not make it inevitable that RCT would become its most famous child, at least make this development explicable with the benefit of hindsight.

\section{Old and new paradigms revisited}

The contrast between old and new paradigms can be further developed by drawing out some implications and structuring assumptions which fall mainly outside Warner's purview.

First, we can consider the two paradigms' contrasting sociological standpoints: in particular, whether they are tilted towards structure or agency. The old paradigm 
strongly emphasises structure and impersonal structural processes, and renders individual choice and agency virtually invisible. On this account, impersonal social processes - like social differentiation - are the focus of interest, with individuals and religious groups assumed to be passive in the face of their advance. By contrast, the new paradigm emphasises individual choice and agency almost to the exclusion of macro-social structures and processes. The latter, if they are considered at all, are considered to be nothing but the aggregation of individual choices. In this paradigm it is individual agency which is the driver of social change and 'society' which falls into the shadows, not vice versa. Warner touches on this issue, but resists this implication. Whilst he acknowledges that the old paradigm in interested in the 'whole society', he contrasts this with the new paradigm's interest not in 'individuals' but in 'social groups' like congregations (Warner 1993, table 1:1052). Part of his justification - besides his own sociological expertise and preference - is that congregations and religious groups are the main focus of the large number of empirical studies which he identifies as exemplifying and advancing the new paradigm. However, a focus on congregations is hardly the same as a focus on society more broadly, and in many ways has the same effect as focusing on individuals, since it too tends to render religion a 'private' rather than a 'public' matter. That the new paradigm has an inbuilt bias towards a privatised conception of religion - or, at least, insufficient sociological ballast to resist it - certainly helps explain why RCT took the course it did.

This point can be developed by looking, secondly, at the different ways in which the paradigms model the religion-society relation or, to put it in spatial terms, how they view the location of religion in society. In the old paradigm, 'real' religion is imagined as a bounded institutional domain with relations to other social domains, particularly the political, and a similar status. In the new paradigm, religion is identified with individuals and groups who inhabit the private sphere: it is separate from the state and the 'real economy', outside the public sphere, and free from its 'interference'. Again we see that for the new paradigm religion is a private matter; for the old it is a public one. At first sight the contrast could not be more marked. If we look more closely, however, we find it diminishes. For although the old paradigm considers historic religion a public matter, its argument is that modern religion has been pushed to the periphery of the public sphere and 'privatised'. Both paradigms agree on this point when discussing religion in the modern world. Their difference is that whilst the new paradigm considers privatised religion powerful and significant, the old considers it socially marginal and inconsequential (for a clear and influential statement of this position see the work of Bryan Wilson, e.g. Wilson 1966).

This point about the different assessments of the social significance of privatised religion leads us, thirdly, to consider the different models of power implicit in the two paradigms. For the new, power resides with the individual consumer and citizen, whose choices shape society. For the old, power resides in the public sphere and its structured forms of social power: political, economic, military and so on. In Sayer's (2004) terms, the old paradigm views power as 'arterial' (as structured by institutions which control scarce resources), whereas the new paradigm views it as 'capillary' (as flowing throughout society, negotiated by individuals, bound up with personal choices, and evident in 
everyday interactions). Because modern religion is considered marginal to the main concentrations of social power, it is treated as inconsequential by the old paradigm. But because the new paradigm considers religion an important determinant of individual choices, and considers such choices to be so significant, it takes a different view. Thus American sociology of religion is much more interested than European in investigating how measurable individual religious commitment affects voting, or health, or happiness. It is also more interested in congregational studies, because, as Warner emphasises, it is interested in the power which religion can exercise by virtue of its ability to forge personal and social identities shaped around congregational loyalties and common moral causes.

Finally, it is interesting to notice an absence in both paradigms, namely their shared lack of interest in religious symbols and material culture. This absence has become more noticeable since Warner's article was written because the interest in these topics has grown so much in the meantime. Admittedly, in this regard the sociology of religion has mainly been catching up with other fields like anthropology and religious studies, which had been aware of the significance of the material dimensions of religion for longer; but it is interesting to note how neither the paradigms Warner outlines are disposed in this direction.

Fig. 1 Similarities and differences between the paradigms

\begin{tabular}{|l|l|l|}
\hline & \multicolumn{1}{|c|}{ Old Paradigm } & \multicolumn{1}{c|}{ New Paradigm } \\
\hline 1.Sociological standpoint & Structure & Agency \\
\hline $\begin{array}{l}\text { 2.Social location of } \\
\text { religion }\end{array}$ & $\begin{array}{l}\text { Religion as public, but } \\
\text { privatised in modernity }\end{array}$ & $\begin{array}{l}\text { Religion located in the } \\
\text { private sphere }\end{array}$ \\
\hline 3.Model of power & $\begin{array}{l}\text { Structured power } \\
\text { (arterial power) }\end{array}$ & $\begin{array}{l}\text { Individual choices } \\
\text { (capillary power) }\end{array}$ \\
\hline $\begin{array}{l}\text { 4.Religious symbols and } \\
\text { material culture }\end{array}$ & Neglected & Neglected \\
\hline
\end{tabular}

Figure 1 summarises my 'revisiting' of differences between the two paradigms in a simple table. What stands out are both the differences and the similarities. The paradigms differ in their models of society and power - indeed they are polar opposites. But they agree in their understanding of the social location of religion and in their neglect of the material and symbol dimensions of religion. This looks like a case of 'thesis and antithesis': of polar opposites which share more than they like to admit, and agree or mirror-image-disagree with one another. Part of the explanation must lie in their rootedness in divergent but intimately-connected historical trajectories: those of the old and new worlds respectively. There is difference-in-similarity because the latter was forged, in part, in conscious opposition to the former. And though the old paradigm is indeed captive to ethnocentric assumptions about the European mode of state-church entanglement as the touchstone of 'real' religion, the new paradigm is equally captive to ethnocentrically U.S. assumptions about the congregation and its individual 
members in a 'free' religious marketplace as the 'real' unit of religious currency. All the more reason, then, to see if the sociological study of religion can move beyond thesis and antithesis. There are some clear signs that it is in the process of doing so.

\section{An emerging paradigm}

My suggestion is that there is an emerging paradigm which many sociologists of religion in both Europe and America - and elsewhere - are currently bringing to birth. It learns things from both the old and new paradigms, but also from other disciplines and developments, and from a more self-critical understanding of 'religion'. The importance of new flows of migration, a growing tension between social democratic and neo-liberal ideologies, new security challenges, the rise of new and improved media of communication, and developments in late capitalism, form a background. Within the sociology itself influential developments include (a) a 'cultural turn', which pays attention not only to social relations and social structure, but also to culture as a social force in its own right, and within that a growing interest in 'material culture', the bodily and the emotional (b) a growing interest in globalisation and, with it, a refusal to consider society as necessarily coterminous with national boundaries, or to focus on developments at a national level at the expense of those at local and global levels (and in their intereconnections) (c) a connected interest in both new and speeded up global flows of communication, and of capital (d) a post-positivistic turn which is, amongst other things, open to the use of a range of methodological approaches and to the use of mixed methods in various forms, and more aware of the situatedness of research and researcher. In other areas, however, the emerging paradigm may have things to offer to general sociology - insights which derive from its attentiveness to what is happening to religion.

The main characteristics of the emerging paradigm as I see it are outlined in Fig.2, and I will discuss them in the same order.

\section{Model of society}

The emerging paradigm expands the sociological stance of both the earlier paradigms by taking seriously structure and agency and culture - and the mutual interactions between them. 'Culture' is also broadened to encompass not only ideas and texts, but images, material objects, spaces, symbols and bodies. This enlarged model of society is represented diagrammatically in Fig.3. I use the term 'material-symbol' as an alternative to 'culture', as it combines insights from academic discourses which speak of 'symbolic imaginaries' and those which speak of 'material cultures'. The arrows between the three 'nodes' in Fig.1 indicate dialectical relations: not only that there is two-way interaction between society, agents, and material-symbols, but that these relations affect and change that which they relate. ${ }^{2}$ 
Fig.2 The emerging paradigm

\begin{tabular}{|l|l|l|l|}
\hline $\begin{array}{l}\text { 1.Sociological } \\
\text { standpoint }\end{array}$ & Old Paradigm & \multicolumn{1}{|c|}{ New Paradigm } & Emerging Paradigm \\
\hline $\begin{array}{l}\text { 2.Social location of } \\
\text { religion }\end{array}$ & $\begin{array}{l}\text { Public, but } \\
\text { privatised in } \\
\text { modernity }\end{array}$ & Private & $\begin{array}{l}\text { Society, agents, } \\
\text { material-symbols }\end{array}$ \\
\hline $\begin{array}{l}\text { 3. Geopolitical } \\
\text { horizon }\end{array}$ & National & $\begin{array}{l}\text { Multi-located } \\
\text { within the social } \\
\text { field }\end{array}$ \\
\hline $\begin{array}{l}\text { 4.Religious economy } \\
\text { Religious monopoly }\end{array}$ & $\begin{array}{l}\text { Religious free } \\
\text { market }\end{array}$ & $\begin{array}{l}\text { Global, local, and } \\
\text { national } \\
\text { negotiating political } \\
\text { and economic } \\
\text { constraints and } \\
\text { opportunity } \\
\text { structures }\end{array}$ \\
\hline 5.Model of power & Arterial power & Capillary power & $\begin{array}{l}\text { Arterial and } \\
\text { capillary power }\end{array}$ \\
\hline 6.Model of religion & $\begin{array}{l}\text { Communal belief; } \\
\text { church-like }\end{array}$ & $\begin{array}{l}\text { Personal belief and } \\
\text { attendance; } \\
\text { congregation-like }\end{array}$ & $\begin{array}{l}\text { Relational; beyond } \\
\text { the church model }\end{array}$ \\
\hline
\end{tabular}

Why has the sociology of religion 'materialised' in this way? In part it is a function of the wider 'cultural turn' in the social sciences, and in part it is the result of learning from other disciplines, including not only general sociology, but political science, gender studies, anthropology, cultural studies and - more recently - geography. It also derives from sociologists of religion taking their empirical findings and field studies seriously, and allowing them to impact upon broader theoretical frameworks. Key figures include Meredith McGuire (2009), Colleen McDannell (1996), and Mary Jo Neitz (Battani, Hall and Neitz 2003) (and, in Religious Studies, Kim Knott and her work on religion and space, e.g. Knott 2005). The fact that these are women influenced by feminist studies is no coincidence, since feminist epistemologies, methodologies and feminist theory have also been influential in the reintegration of the body, material culture and labour into theoretical reflection. 


\section{Fig.3 Enlarged sociological model}

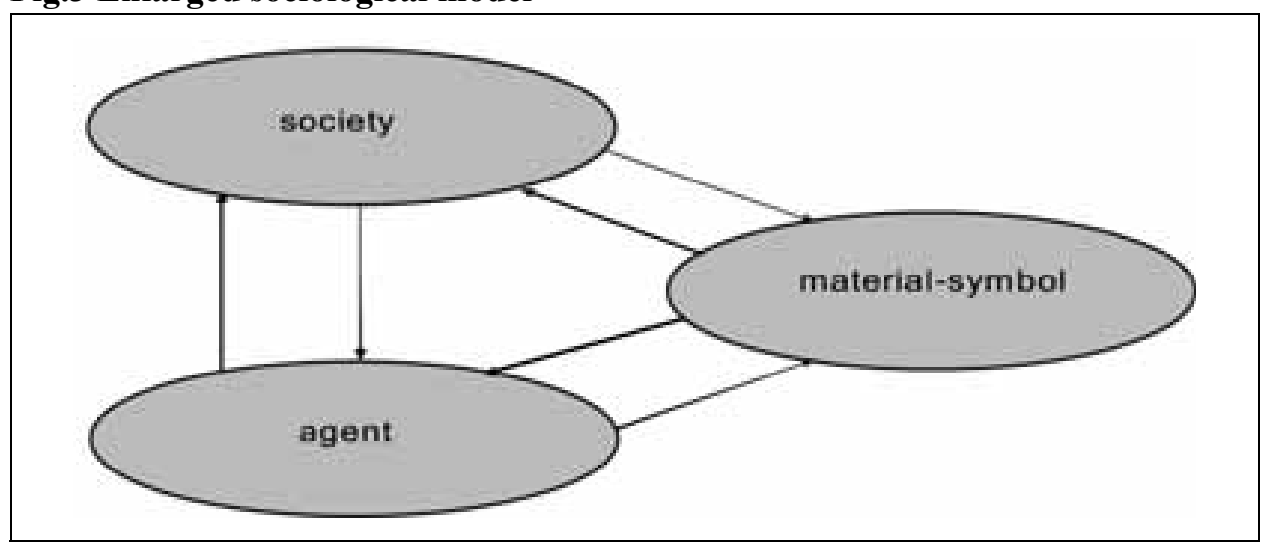

\section{Social location of religion}

The emerging paradigm also takes a different view of the social location of religion. José Casanova took an important step in Public Religions in the Modern World (1994) in which he argued that although religion in modern societies had been differentiated from other social spheres, and may even have been privatised, 'de-privatisation' has recently occurred in a number of national contexts. In Public Religions, however, Casanova's chief examples are denominational churches whose de-privatisation consists in their making normative interventions in civil society. His case studies of de-privatisation involve national-level church authorities making moral interventions which have an influence upon politicians and policies at state -level. For Casanova, in other words, contemporary public religion is still understood as church-like, but as church which tries to influence the state in the style of the USA, rather than through established links and dependencies, in traditional European style.

The emerging paradigm follows Casanova's dissatisfaction with a simple dichotomy between public and private religion, but goes further. Casanova does not abandon the public/private dichotomy but modifies it by introducing the mediating category of 'civil society', and arguing that this is the sphere in which de-privatised religion is active. That is a helpful first step, and takes us beyond the old and new paradigm's agreement that religion in modern societies is privatised. But the emerging paradigm (a) abandons the epistemological nationalism of public/private/civil society discourse (see the next point, point 3 ) and (b) remains open to the possibility that religion may be located, and institutionalised, in a multiplicity of areas in various social domains. Public and politically-significant religion, in other words, takes a wide range of forms in contemporary society, not all of which have the nation-state as their reference point. Take holistic spirituality, for example, which is dismissed as privatised by the old and new paradigms and by Casanova (1994: 4-5). Once we abandon the public/private options and really look to see where this style of religion has social influence, we find it in education, in the workplace (e.g. in management trainings), in the beauty industry, the leisure industry, and in both state-funded and private healthcare (including doctors' surgeries and hospitals). To claim that such religion is privatised is misleading. 


\section{Geopolitical horizon}

Remaining with the example of contemporary spirituality, if we look only at how religion is institutionalised within the boundaries of nation-states (as do the existing paradigms), we miss something else very important. Spirituality is one example of a form of contemporary religion which has local manifestations, and global ones, but fewer national ones (unlike the old state churches). It may be characterised as a 'project' or 'feeder-project' in global civil society, alongside other analogous projects such as feminism or the green movement (Woodhead Forthcoming; the notion of a project in global civil society is from Walby 2009). It may also be looked at in its local instantiations - as many recent empirical studies do. But its national manifestations are few, and it tends not to have national leadership and representation, nor to take the nationstate seriously in its own thought, practice and symbolism. As such, it is a good example of Roland Robertson's (1995) interpretation of globalisation as an intensification of significance of the 'glocal' - the local in interaction with the global. Spirituality is by no means the only example of contemporary religion which is best served by an emerging paradigm which refuses to take the national as its main frame of interest. Religions like Sikhism, Hinduism and Islam carried to Europe by recent migration are also illuminated by being considered not only in national frame and local frames, but in terms of the trans-national locations and commitments of their adherents, symbols, and collective memories. Peter Beyer's Religions in Global Society (2006) shows what such an enlargement of horizons can mean in theoretical terms for the sociological study of religion.

\section{Religious economy}

Central to the gestalt of the new paradigm is the metaphor of a religious economy and, above all, a religious free market. This has proved an inspiration for new insights and research agendas. As Warner points out, however, the interpretive possibilities of the image are not exhausted by a stark contrast between unregulated free market (demand led) and state-regulated monopoly (supply led). The first assumes a situation in which state (and state church) is the most powerful actor in society (old paradigm), the second assumes one in which the economy is most powerful, and the market (including the religious 'market') is cut loose from state interference (new paradigm). The emerging paradigm differs. Instead of limiting its attention to religion-and-the-state or a (religious) marketplace wholly detached from the state, it pays more attention to the actual configurations of political and economic power in contemporary society, and how they impact on religion. For example, Tuomas Martikainen (2009) considers the significance of neo-liberalism for religion, including in the way in which it encourages states to enter into contract-based partnerships with groups in civil society, including religious groups. Such partnerships are intended to secure certain goods for the state and civil society, including enhanced security, social cohesion, and more cost-effective delivery of welfare (Dinham, Furbey, and Lowndes 2009). Whilst abiding by the rhetoric of devolution of power from state to market and civil society, such 'new public management' does indeed provide new options for 'faith communities' and 'faith- 
based organisations', but with a price which includes state control (Dinham 2009; see also the emerging findings of the WREP and WaVE projects on religion and welfare in Europe $^{3}$ ). This is merely one example of the way in which the emerging paradigm refuses to see religion as a self-contained 'economy' isolated from the real state and economy, but is interested in how a religious economy interacts with contemporary currents in the 'real' economy and polity. Another example would be the amount of attention which is now being paid to the importance of law in regulating religion, especially in north American (e.g. Sullivan 2005; Beaman 2008), although the importance of a new raft of anti-religious-discrimination legislation in Europe is also of interest. As these examples of neo-liberalism and EU law show, the political and economic currents which are affecting religion are not necessarily confined to national boundaries. To sum up: rather than viewing public religion as regulated by the nation-state, or as a self-contained 'marketplace' free from state influence, the emerging paradigm seeks to investigate how religion negotiates with the constraints and opportunities offered by changing political, legal, and economic structures at local, national and transnational scales.

\section{Model of power}

The old paradigm identified power with arterial power, particularly the power of the state. The new paradigm, in the guise of RCT, identifies power chiefly with individual choices and their aggregation. Warner, in his advocacy of the new paradigm, focuses more on the 'congregational' power which arises from the creation of shared identities focused on common values, and which can sometimes be mobilised for political causes. The emerging paradigm draws on all these insights and attempts to co-ordinate them. Thus it is interested in religion in relation to structural power, for example in how state power and legislative regimes create constraints and opportunity-structures for religion, as well as the ways in which religion may mobilise groups to engage with or subvert these structures (see point 4 above, and Beckford and Gilliat's (1998) work on religion in prisons). It is also interested in how religion provides a resource whereby minority communities can resist policies, identities and choices imposed on them by a majority - for example, the way in which many so-called 'Asians' and 'Pakistanis' in Britain rejected the ascription of a race-based identity, and claimed instead the designation 'Sikh', 'Hindu' or 'Muslim', and chose to demonstrate their identity by way of visible symbols including hairstyle and clothing - including Sikh beards and turbans, and Muslim veils (e.g. Bauman 1996; Singh and Tatla 2006). The emerging paradigm also takes seriously power relations within religious groups and communities, and the ways in which religious empowerment and disempowerment arise from unequal distribution of resources of different kinds, including symbolic resources. Rather than keeping these interests in arterial and capillary power separate, it is becoming clear how important it is to integrate them. For example, in order to understand controversies over Islam and the Muslim veil in Europe, it is necessary to consider state policies, citizenship and migration regimes, scriptural and theological interpretations of hijab in 
Islam and intra-Islamic debates over the issue, and the meanings which veiling has for individual women who adopt it.

\section{Model of religion}

The emerging paradigm takes a broader view of religion than the earlier paradigms. For the old paradigm, religion was primarily cultural. It provided meaning and solidarity and helped make sense of a senseless world (Berger 1967; Luckman 1967). With modernisation its political power had drained away, and with it its ability to provide solidarity, leaving only a residual cultural function. The new paradigm construed religion as a matter of personal belief (in supernatural beings and rewards), backed up by membership in religious congregations and certain practices like prayer. In contrast to these views, with their rootedness in church and congregational modes of religion respectively, a more holistic understanding has emerged which views religion in terms of the interrelations between a religious community, individuals who identify with it, and their sacred symbols (see Fig.3). This enlarged relational understanding is evident in the way that recent work in the sociology of religion has given much greater attention to, for example, bodily practices (e.g. Mellor and Shilling 1997), emotions (e.g. Riis and Woodhead 2010), collective symbols (e.g. Orsi, 2005; Zubrzycki 2006), and material culture (e.g. Morgan 1998). But this is not the only sense in which the new model of religion is more relational, for religion (conceived relationally as a regime of social and symbolic relations) is also being studied in relation to wider global as well as national society and culture, not in isolation from it.

Thus religion is understood by the new paradigm as a modality of power in the modern world, which struggles for its status with other 'fields', which is subject to pressure for anti-religious sectors of society, and which is structured internally by different access to resources and influence on rules within the field (Riis 2009). Simultaneously, the longstanding sociological bias towards a view of religion as monotheistic and church-like (whether European-style church or American-style congregation) is being replaced by an understanding which is more open to religious diversity. Warner's references are still largely to studies of congregations, Christian and Jewish. But recent decades have seen a slow and steady growth in studies of, for example, neo-paganism, feminist spiritualities, trance- and experience-based religion, landscape-based religion, and other forms of animistic, 'polytheist', syncretistic, non-congregational religion (e.g. Berger 2005; Rountree 2004; Brown 1997; Ivakhiv 2001). ${ }^{4}$ In addition, sociologists are slowly starting to pay greater attention to non-Christian 'world' religions, especially Islam, and to religion in a global context (e.g. Gilliat-Ray 2010; Kurtz 2006; Beyer 2006). In this regard they are learning from and catching up with bordering disciplines of anthropology and religious studies.

\section{Methodological implications}

Some of the main methodological implications and characteristics of the different paradigms can also be displayed in tabular form: 
Fig.4 Methodological Implications

\begin{tabular}{|l|l|l|l|}
\hline & Old Paradigm & New Paradigm & Emerging Paradigm \\
\hline $\begin{array}{l}\text { Methodological } \\
\text { Focus }\end{array}$ & $\begin{array}{l}\text { Society, social } \\
\text { processes }\end{array}$ & $\begin{array}{l}\text { Individuals and } \\
\text { groups of individuals }\end{array}$ & $\begin{array}{l}\text { Interactions (social } \\
\text { and symbolic) }\end{array}$ \\
\hline Agenda & Decline of religion & Vitality of religion & $\begin{array}{l}\text { Religious change in } \\
\text { context }\end{array}$ \\
\hline Methods & $\begin{array}{l}\text { Theorising about } \\
\text { social processes }\end{array}$ & $\begin{array}{l}\text {-surveys (individual } \\
\text { attitudes and beliefs) } \\
\text {-interviews } \\
\text {-survey + interview } \\
\text {-congregational } \\
\text { studies }\end{array}$ & $\begin{array}{l}\text { Range of methods } \\
\text { relevant to different } \\
\text { aspects of religion } \\
\text { and society }\end{array}$ \\
\hline
\end{tabular}

Warner's original article does not discuss the methodological implications of the old and new paradigms, and I can only make brief remarks. Some comment seems needed, however, since epistemology, theory, concepts, research design, and method are so closely bound up with one another, that shifts in the theoretical paradigm like those we have been discussing are bound to have implications elsewhere.

To put it simply, perhaps crudely, the old paradigm, being chiefly interested in structural processes was methodologically disposed towards observation of, and etic commentary upon, social structures and processes. The sociologist took the role of the informed observer of society, and used his position as a trained member of that society to reflect critically upon it. Hermeneutical and phenomenological epistemologies were often invoked in relation to this approach. The sociologist might also be informed by empirical work, including case studies, usually carried out by others. Today a similar kind of high-range sociological enterprise (though not much interested in religion) tends to fall under the label of social theory. In its aim, the old paradigm sociology of religion was chiefly focused upon an enlarged understanding of society, without the sort of meliorative agenda which is characteristic of what Burawoy $(2004,2005)$ calls 'public sociology'.

The new paradigm, by contrast, focuses its interest on religion as an individual and congregational matter, and concentrates its interest accordingly on the micro- and meso-levels of society. Favoured methods include the survey, interviews, and congregational studies; or some combination of these. In the case of RCT in particular, because it is focused upon a general theory of religion and religious vitality, it favours surveys which, as the world suggests, offer a shallow view with wide range. Such surveys tend to focus on individual behaviours, practices, beliefs or attitudes, which are taken to be good measures of religiosity, and which can be correlated with information concerning religious supply in a particular 'marketplace'. These preferred methods are tied up with the new paradigm's conception of religion as private rather than public: 
public religion is visible for any observer to see; private religion requires insiders to divulge their commitment.

In methodology as elsewhere, the old paradigm's interest is therefore in structure, and the new paradigm's in agency. Neither generalisation should be pushed too far: recent RCT has become more interested in the supply-side of religion, and the old paradigm did not wholly ignore individual choices; but the difference in orientation is apparent. The emerging paradigm is bound by neither preference. In its understanding of religion it is likely to be non-essentialist, identifying it neither with an inner experience nor a particular type of cultural or social form, but viewing it as a label which is assigned to - and claimed by - certain shifting social-symbolic formations. In that sense, it is a social construction (Beckford 2003). This has methodological implications. Just as society is a complex phenomenon, so religion, which can be identified with many different aspects of society, requires a methodology which has a toolkit of different methods, some more appropriate to the study of structure, some to agency, some to culture and material-symbols. The research question, and the aspect of society with which it is concerned, will determine the choice of methods. To rely on interviews and attitudinal surveys would be appropriate, for example, in research which sought to probe the articulated reasons of British Muslim women for adopting hijab. It would be inappropriate, however, if the aim was to establish why these women adopted hijab (since there would be 'structural' reasons of which they were unaware, or unwilling to admit, and which could better be established by ethnographical methods and immersion in these women's social and symbolic networks, comparative and historical studies - e.g. with British Sikhs and the turban, and reflection on what social advantages accrue from such a choice in the contemporary climate of opinion, legislation, political opportunity for religion etc.). If the research question were broadened even further and the aim was to find out why the practice had become so controversial across Europe, an even larger suite of carefully-chosen and skillfully-combined methods would be required, some perhaps more typical of other disciplines (e.g. frame analysis of media controversies, political analysis of citizenship and immigration regimes, legal analysis of legislation and recent cases, semiotic and psychological analysis of hijab as a symbol with powerful positive and negative motivational force).

The emerging paradigm is therefore open to a wider range of methods, and methodological innovations, than has been characteristic of sociology of religion under the existing paradigms. This should not be misunderstood to mean that every practitioner of the new paradigm must exemplify the entire range of methods, but that its implicit vision of sociology of religion (and society) as a whole is such that it should be open to the employment of such a range of methods. This has additional benefits, including the ability to triangulate findings yielded by different methods, and thus establish validity - a particularly important issue if qualitative as well as quantitative research is to be taken seriously, both inside and outside the academy. Moreover, it allows the subdiscipline to function as a whole, rather than as a set of competing narratives, theories, or paradigms vying for supremacy in a zero-sum game. 


\section{Conclusion}

I have resisted the temptation to say that the emerging paradigm is the outcome of a dialectical process and that it represents a synthesis which emerges from the contradictions between the thesis and antithesis of the old and new paradigms. To do so would misrepresent the significance of the shift which is taking place in the sociology of religion, and the novelty of what is coming into being. Both the old and new paradigms are focused around a theory or, some would say, a narrative: in the first case one of religious decline, in the second of religious growth. The emerging paradigm is not tied as closely to a particular theory, nor to a particular 'angle' on society, nor to a particular methodology. Consequently, what I have been trying to sketch is different in kind. It concerns a new vision of the sociology of religion in which the sub-discipline ceases to be based around competing theories, but is able to embrace different epistemologies, methods, theories and research questions in a more synthetic manner. This is not a reflection of epistemological relativism, but of an expanded understanding of religion and society which is better able to specify the scope and limitation of different projects and theories, and to judge their compatibility or incompatibility accordingly.

If I were to sum up what is characteristic of the emerging paradigm in a single word, I would say 'relational'. Religion is conceptualised not as not a 'thing' - whether a 'social fact' or a personal one - but as a set of social relations focused around particular symbols (which relate adherents to a supra-social beings and realties) and associated values. Such relations have the potential to empower those who enter into them, often in ways which would not be otherwise socially available. Religion is a modality of power in the late-modern world, a domain which engages in local, national and global levels and struggles with a range of powerful 'secular' (anti-religious) and religious actors and competitors. It is capable of insinuating itself within many different social locations, and influencing a wide range of constantly-changing societal interactions. It has the potential to set people in new relations with themselves, supra-social beings (Gods, ancestors, evil spirits and so on), and other social groups. Thus both social and symbolic relations lie at the heart of this vision of religion, and the scholar alternately enters into them, stands outside them, and employs a range of different tools and theoretical perspectives to try to make sense of them, and to communicate their meaning to other scholars, funders, and interested parties in as responsible and truthful a way as possible.

This expanded approach has learnt from both the old and the new paradigms, and tries to combine the insights of both, without succumbing to the methodological nationalism which lies at the root of some of their most obvious agreements and disagreements. This is the other reason why I do not think it represents a 'synthesis'. The antagonism and mirror-imaging of old and new paradigms seems tightly bound up with their national origins and commitments, and - more recently - with an associated clash between social democratic and neo-liberal ideologies. As I have tried to show, it is an essential feature of the emerging paradigm that it is not captive to such concerns. The fact that it is global in its vision, sensitive to a more mobile and 'mediatised' world, and that its exemplars come equally from both sides of the Atlantic and elsewhere, 
seems important. This, and its ability to sustain a greater openness to a wider range of methods and perspectives may, over time, enable it to make an important contribution not only to the study of religion, but to the reintegration of the sociology of religion into mainstream sociology.

\section{Notes}

1 Thanks to the organisers of the conference, especially to Tuomas Martikainen of Åbo Akademi, and to Inger Furseth and Pål Repstad for encouraging the publication of this article.

2 Thanks to Ole Riis who prepared the diagram. This view of society is developed in relation to religious emotion in Riis and Woodhead (2010).

3 These large research projects, funded by the Bank of Sweden and European Commission respectively, are directed by Anders Bäckström of the University of Uppsala.

4 The study of NRMs was pioneering of some of these developments, but was often particularly drawn to bounded forms of religion which had quasi-congregational features.

\section{References}

Ammerman, Nancy Tatom 1987. Bible Believers. Fundamentalists in the Modern World. New Brunswick and London: Rutgers University Press.

Battani, Marshall, John Hall and Mary Jo Neitz 2003. Sociology on Culture. London and New York: Routledge.

Baumann, Gerd 1996. Contesting Culture: Discourses of Identity in Multi-Ethnic London. Cambridge: Cambridge University Press.

Beaman, Lori G. 2008. Defining Harm: Religious Freedom and the Limits of the Law. Vancouver, Toronto: UBC Press.

Beckford, James 2003. Social Theory and Religion. Cambridge: Cambridge University Press.

Beckford, James and Sophie Gilliat 1998. Religion in Prison. Equal Rites in a Multi-Faith Society. Cambridge: Cambridge University Press.

Berger, Helen (ed.) 2005. Witchcraft and Magic: Contemporary North America. Philadelphia: University of Pennsylvania Press.

Berger, Peter L. 1967. The Sacred Canopy. Elements of a Sociological Theory of Religion. Garden City, New York: Doubleday.

Beyer, Peter 2006. Religions in Global Society. London and New York: Routledge.

Brown, Michael F. 1997. The Channeling Zone. American Spirituality in an Anxious Age. Cambridge, MA: Harvard University Press.

Burawoy, Michael et al. 2004. Public Sociologies: A Symposium from Boston College. Social Problems 51 (1):103-130.

Burawoy, Michael 2005. The Critical Turn to Public Sociology. Critical Sociology 31 (3): 314 326.

Casanova, José 1994. Public Religions in the Modern World. Chicago and London: University of Chicago Press.

Cott, Nancy 1977. The Bonds of Womanhood: 'Women's Sphere' in New England, 1780-1835. New Haven, Conn.: Yale University Press. 
Davidman, Lyn 1991. Tradition in a Rootless World: Women Turn to Orthodox Judaism. Berkeley, Los Angeles, Oxford: University of California Press.

Dinham, Adam 2009. Faith, Public Policy and Civil Society: Policies, Problems and Concepts in Faith-Based Public Action. London: Palgrave Macmillan.

Dinham, Adam, Robert Furbey, Vivien Lowndes (eds.) 2009. Faith in the Public Realm. Controversies, Policies and Practices. London, Policy Press.

Gilliat-Rey, Sophie 2010. Muslims in Britain. An Introduction. Cambridge: Cambridge University Press.

Herberg, Will 1960. Protestant, Catholic, Jew: An Essay in American Religious Sociology, $2^{\text {nd }}$ ed., Garden City, N.Y.: Anchor.

Ivakhiv, Adrian 2001. Reclaiming Sacred Ground. Pilgrims and Politics at Glastonbury and Sedona. Bloomington: Indiana University Press.

Knott, Kim 2005. The Location of Religion: A Spatial Analysis of the Left Hand. London: Equinox.

Kurtz, Lester 2006. Gods in the Global Village: The World's Religions in Sociological Perspective. $2^{\text {nd }}$ edition. Thousand Oaks, CA: Pine Forge Press.

Lechner, Frank J. 1997. The 'New Paradigm' in the Sociology of Religion. Comment on Warner. American Journal of Sociology 103(1): 182-192.

Luckmann, Thomas 1967. The Invisible Religion. London: Collier-Macmillan.

Martikainen, Tuomas 2009. Reframing Islam and Muslim Identities: Neoliberalism, Minority Governance and the Welfare State in Finland. Unpublished paper presented at the 'Living Islam in Europe' conference, 7-9 May 2009, Zentrum Moderner Orient, Berlin.

McDannell, Colleen 1996. Material Christianity: Religion and Popular Culture in America. New Haven, CT: Yale.

McGuire, Meredith 2009. Lived Religion. Faith and Practice in Everyday Life. New York and Oxford: Oxford University Press.

McLeod, H. 2007. The Religious Crisis of the 1960s. Oxford: Oxford University Press.

Mellor, Philip and Chris Schilling 1997. Re-forming the Body: Religion, Community and Modernity. London: Sage.

Morgan, David 1998. Visual Piety: A History and Theory of Popular Religious Images. Berkeley: University of Berkeley Press.

Niebuhr, H. Richard 1987/1929. The Social Sources of Denominationalism. Gloucester: Peter Smith.

Orsi, Robert A. 2005. Between Heaven and Earth: The Religious Worlds People Make and the Scholars who Study Them. Princeton and Oxford: Princeton University Press.

Riis, Ole 2009. The Epistemological Issue in the Study of Religion. Unpublished paper delivered at the 'International Society for Sociology of Religion' conference, Santiago de Compostela, 2009.

Riis, Ole and Linda Woodhead 2010. A Sociology of Religious Emotion. Oxford: Oxford University Press.

Robertson, Roland 1995. Glocalization: Time-Space and Homogeneity-Heterogeneity.' In Global Modernities, edited by Mike Featherstone, Scott M. Lash and Roland Robertson, 2544. London: Sage.

Sayer, Andrew 2004. 'Seeking the Geographies of Power'. Economy and Society 33 (2): 255270.

Rountree, Kathryn 2004. Embracing the Witch and the Goddess: Feminist Ritual-Makers in New Zealand. London: Routledge. 
Singh, Gurharpal and Darshan Singh Tatla 2006. Sikhs in Britain: The Making of a Community. London: Zed Books.

Smith-Rosenberg, Caroll 1985. Disorderly Conduct: Visions of Gender in Victorian America. New York: Knopf.

Sullivan, Winnifred 2005. The Impossibility of Religious Freedom. Princeton: Princeton University Press.

Walby, Sylvia 2009. Globalization and Inequalities. Complexity and Contested Modernities. London: Sage.

Warner, R. Stephen 1993. Work in Progress toward a New Paradigm for the Sociological Study of Religion in the United States. American Journal of Sociology 98:1044-1093.

Warner, R. Stephen 1997. A Paradigm Is Not a Theory: Reply to Lechner. American Journal of Sociology 103:192-198.

Warner, R. Stephen 2005. A Church of Our Own. Diversity and Disestablishment in American Religion. New Brunswick, N.J.: Rutgers University Press.

Wilson, Bryan 1966. Religion in Secular Society: A Sociological Comment. London: Watts.

Woodhead, Linda 2004. An Introduction to Christianity. Cambridge: Cambridge University Press.

Woodhead, Linda Forthcoming. New Forms of Public Religion: Spirituality in Global Civil Society. In Religion, Public or Private?, edited by Wim Hofstee and Arie van der Kooij. Leiden: Brill.

Zubrzycki, Geneviève 2006. The Crosses of Auschwitz: Nationalism and Religion in Post-Communist Poland. Chicago and London: University of Chicago Press. 